I refer, of course, to the new medical assistants to be squeezed out of senior hospital medical officers. The Ministry's proposals for a new staffing structure in our hospitals divide these senior hospital medical officers into two classes, those with the special award for acting as consultants and those without it Admittedly the S.H.M.O.s of the first class may pass through yet another review from which some perhaps will emerge consultants in name as well as in fact, but the remainder and all those of the second class will become medical assistants. And as no mention is made of the third class of S.H.M.O.s (those who have been recognized by their regional hospital boards as holding consultant posts but refused the special allowance for doing this work), perhaps indeed because few people realize that such a truly splendid and endear ingly British anomaly exists, is it not reassuring to think that these doctors too will be bidden to take their enthusiasm and the knowledge gained while working as consultants into the shining ranks of newly discovered medical assistants ?

Two minor difficulties present themselves and are it must be confessed a little puzzling but no doubt they can be easily explained. Exactly whom will these new assistants assist? And since consultants are already in short supply where could they find the time necessary effectively to supervise their new assistants ? As the years go by these assistant medical attendants will very likely acquire a certain experience, but in the beginning and while still new to their posts it will really be quite essential for someone to spend a great deal of time in overlooking them.-I am, etc.,

$$
\begin{aligned}
& \text { St. Wulstan's Hospital, } \\
& \text { Malvern, Worcestershire. }
\end{aligned}
$$

\section{Future of General Practice}

SIR,-A meeting of the Lancaster Division of the B.M.A. held recently came to certain conclusions, of which the following is a summary.

With all its drawbacks it believed the basic concept and inception of a free service for the sick to have been one of the most civilized acts of human progress in our time. It was not convinced that the doctor-patient relationship had suffered; in many ways the removal of a financial barrier had given the N.H.S. doctor the strength of disinterestedness. There was a new relationship, perhaps no worse for being less obviously materialistic.

Most members appeared to be unimpressed by the melancholy claim that the family doctor's status was declining. The one constant complaint was the need of the family doctor for time. The meeting believed that consultation was at the heart of good medicine and its place was never likely to be superseded, no matter how sophisticated and complex become the machines of diagnosis. $\mathrm{Re}$ spect, confidence, and trust were not things born of rush and hurry. There must be time for the patient, time to study, time to relax.

The Division aligned itself with many of the recommendations of the Sheffield Local Medical Committee (Supplement, 5 September, p. 127), in particular its specific plan for relieving the family doctor of the crippling burden of " compulsory perpetual responsibility." It also agreed with the plan for dealing with complaints against the repeated abuse of the services by the patient. It seemed to the Division a particularly dis graceful state of affairs that though the family doctor is responsible for over $80 \%$ of the total work load of keeping the nation fit there was not and never had been a planned development of the practitioner services.

The Division recommended the abolition of the Pool and that all general practitioners should be paid $£ X$ per annum per patient. This sum should have two components: (1) The capitation fee for general medical services to the patient, which should be something considerably better than the present average of $4 \mathrm{~s}$. per item of service. (2) To this should be added a second amount representing the, average expenses incurred per patient per year. This should be based on a proper actuarial assessment of a proper sampling of practices. The aggregate capitation fee, when agreed, should remain constant until any changes are suggested by the Reviewing Body, in much the same way as the consultants' pay is treated. All other earnings within the framework of the N.H.S but outside general medical services-vaccinations, maternity services, hospital appointments, etc.-should be paid separately and in addition to the capitation fee.-We are, etc.,

$$
\begin{gathered}
\text { FRANK S. RICKARDS, } \\
\text { Chairman, } \\
\text { J. L. WARD, } \\
\text { Secretary, } \\
\text { Lancaster Division. }
\end{gathered}
$$

\section{Practice Expenses}

SIR,-I should like to comment on $\mathrm{Mr}$ Anthony Barber's statement (Supplement, 26 September, p. 135). He states that he and the B.M.A. " expect that the new scheme will encourage doctors to employ more ancillary help and ... the taxpayer will provide additional money. I should be surprised if the eventual extra cost does not amount to several million pounds" (my italics).

None of this extra money is to be found now. Meanwhile, if 10,000 general practitioners employ ancillary help costing $£ 500$ a year, approximately $£ 3 \mathrm{~m}$. will be required to reimburse $£ 300$ directly to each doctor. The Expenses Pool would be reduced from, say, $£ 34 \frac{1}{2} \mathrm{~m}$. to $£ 31 \frac{1}{2} \mathrm{~m}$., on average about $£ 1,370$ per doctor. Each doctor employing help will receive direct repayment of $£ 300$ p.a. plus, if he is the average doctor, a further $£ 1,370$, making $£ 1,670$-an increase of $£ 170$ (not $£ 300$ ) in gross income. The other 13,000 general practitioners will receive on average $£ 1,370$-an average decrease of $£ 130$ a year in gross income.

The Minister states that the average net pay will not be reduced. I accept this, but to the average general practitioner whose gross income is reduced by $£ 130$ p.a. the final result is the same whether the reduction is suffered in "salary" or expenses.-I am, etc.,

$$
\text { Belfast } 14 .
$$

$$
\text { W. D. KinLEY. }
$$

SIR,-The cardinal error has been the presentation to the Review Body of a memorandum on remuneration instead of a general memorandum to the Government for a review of the contract of services of general practitioners, including a review of net remunera- tion and expenses. Now we are involved in a dissipation of effort and energy in discussing net remuneration with the Review Body, expenses with the Minister, and terms and conditions of service with the Fraser Working Party. It is clear that the Treasury will not allow the Minister to award full direct reimbursement of expenses if it is still in the dark as to the total net remuneration which the Review Body will recommend. But that is nothing new. Had adequate remuneration been assured from the beginning the problem of the expenses factor would scarcely exist.

Unfortunately, two recent utterances from Dr. I. M. Jones-the spokesman for so many of us-only reinforces the fear that in any future revision of general practitioners' contracts in the N.H.S.- - a step I advocated more than two years ago ${ }^{1}$-the same glaring fundamental error will be perpetuated. Dr. Jones is quoted (Supplement, 29 August, p. 123) as saying, "throughout the discussions with the Ministry the negotiators had envisaged the continuance of the general practitioner as an independent contractor." And in his letter (3 October, p. 879) Dr. Jones writes: "The new scheme... represents the direct reimbursement for the cost of ancillary staff which can be achieved without prejudicing the position of the doctor as an independent contractor and without risk of the imposition of intolerable restrictions upon his freedom."

It would seem that here, astute though Dr. Jones undeniably is, he is echoing exactly what the Treasury, through Mr. Anthony Barber, wants us to continue to believe. The Minister has been quoted as saying that a greater amount of direct repayment of expenses to general practitioners might entail undue probing and inquiry by the Treasury which would be incompatible with the independence of the family doctor as an independent contractor in the N.H.S. (Was not general practice nationalized in 1948 , or have we forgotten ?) The general practitioners must now fight this ministerial sleight-of-hand with all the force at their command.

The consultants receive their net remuneration for treating N.H.S. patients: their N.H.S. expenses are met entirely by the State. The general practitioners will no longer be content with one-third of this or two-thirds of that. The news that those of us in single-handed practice or in partnerships of two who have sunk capital-without any help from the Group Practice Loans Committee-in new premises in the past few years would have been better off had we waited for grants to renovate or improve old and ageing premises is surely an insult.

Two things our negotiators must make plain to the new Minister. First, the general practitioners of this country do not accept that in asking for a full direct repayment of their expenses and capital outlay in treating their N.H.S. patients they are asking the Government for any more than simple justice, long overdue in all conscience. Secondly, the general practitioners do not feel any threat to their independence need be feared in any sensible method which meets the above requirements. If the farmers of this country have been subsidized to the extent of many millions over the years without any inroads on their independence I fail to see why the general practitioners of this country should be scared. Moreover, if one examines the extent to which manufacturing industry is so 